\title{
Artistic Representation in Contemporary Kuwatit, Egyptian, and Iranian Paintings and Prints and Some Interpretation of These Works According To Islamic Law
}

\section{Faridah Mohammad}

The Quran (the sacred book) prohibited the making of idols, yet varying degrees of image making may be observed in the Islamic world. My research explores the variations in contemporary artistic representation in Kuwait, Egypt, and Iran. The hypothesis I explore is that variations to be found in the works of these countries could be accounted for by different interpretations of the Quran's prohibitions of idols. I have already completed field research in Kuwait, Egypt, and Iran to document artistic representation and to identify different interpretations.

Four artists from each country were chosen and one work of each was analyzed. I identified the characteristic features, the influence of religion and tradition, on each work. I also interviewed two Ulama from each country (an Arabic term for clerics) to clarify how they view art expression. Views of both major divisions or sects, the Sunni and the Shiite, were considered. A comparison of the Ulama's differing interpretations tended to support the hypothesis that variations in the works were indeed influenced by religious law, even while the same styles are practiced in Kuwait, Egypt, and Iran; namely, realism, surrealism, impressionism, abstraction, representation, cubism, landscape, still life, and calligraphy.

In Kuwait, the aesthetic features of the works derive solely from Islamic art tradition and culture. Figures with two dimensions, i.e., in graphic work, are allowed to be developed in exhibitions and galleries, but they are not found in the public domain. Three-dimensional figures are strictly prohibited.

Some Egyptian artists, on the other hand, incorporated subject matter taken from the national tradition as well as Islamic art tradition. Two-dimensional works are produced with some restrictions. For example, representation of nude figures is permitted in two dimensions, although not in the public domain. Nude figures are not allowed in three-dimensional works.

Similarities were also found in Iran as themes are taken from Iranian tradition, yet they exhibited intra-national differences based on the artist's location, for example, as in Isiahan and Khorasan. Two and three dimensional

Marilyn Zurmuehlen's Working Papers In Art Education 1994-1995 
figures are displayed in the public, but the same restrictions apply to the use of nude figures as in Egypt.

Differences found in Kuwait and Egypt may be attributed to the cultural traditions. Despite the fact of Egypt being Sunni and Iran being Shiite, they share a long tradition of civilization. For Iran and Egypt two and three-dimensional themes are on view in the public domain, while Kuwait is more restrictive with regard to two and three-dimensional images.

The Ulama's interpretations varied from one country to another. These varying interpretations have their respective roots in the culture. The disagreement among the Ulama did not touch upon the unity of God, the basic religion, and the tradition, but rather involved specific details which affected people's lives. For example:

1. Tribal affiliation.

2. Political leadership.

3. Outside influence by non-Muslim.

4. Philosophic interpretations.

The variations in interpretation are related to other factors that have influenced artistic representation. These factors are social, historical, cultural and individual. Although there is one Islamic law, the application of the doctrine differs from one country to another because of the uniqueness of their culture, heritage and religious interpretation.

Art in Islamic countries shares common aspects of the traditional heritage and Western modernity:

1. The training of all modem artists, whether at home or abroad, is Western-oriented and follows Western norms, aesthetics and rules.

2. Yet, most Islamic artists share a common search for their identity, in a way that will allow them to combine their Eastern origins with their Western education and way of life.

3. Almost all modern Islamic artists, even those in the most progressive countries, have a problem communicating with their own societies. As in the west, artists tend to be alienated from the public. There are notable disparities between countries of the Islamic world, not only in their standard of living, but also in the development of the modern movement in each country. The

Marilyn Zurmuehlen's Working Papers In Art Education 1994-1995 
prosperity of a country by no means reflects its cultural and artistic progress (Wijdan, 1989, p. 12).

\section{Suggestions for Resolution}

Industrial society occupies a unique position in history and geography. A religious authority in an Islamic country should present seminars and address a living artistic tradition of their respective country for the purpose of clarifying and interpreting it for the faithful people.

Being an artist/researcher, I suggest seminars and conferences be held, not for a negative purpose, but rather as an attempt to advance the artistic tradition in light of the Quran, and the respect of different cultures, and in order to recoginize the development of special terminology in the artistic tradition.

As a committed art researcher, and as a religious person, I make these modest suggestions:

1. I need to expand my inquiry as an art educator in my college to strengthen Kuwaiti society through art curriculum and to strengthen the student of art education in light of this research.

2 As an artist, I want other artists in the non-Islamic world to appreciate the motivation and inspiration now in several developmental directions among Islamic artists and cultures, so that they may appreciate contemporary Islamic art.

3. As an artist researcher working in ISALTA (International Society For The Advance Of Living Tradition In Art), I will help organize seminars and conferences to produce norms.

4. A series of conferences, in effect, may help the Ulama and the artist incorporate for further appreciation of the advancement of living tradition. 